\title{
Neonatal Male Circumcision
}

\author{
Mark Stephen Umoh* \\ Department of Surgery, University of Calabar, Nigeria
}

Submission: May 16, 2017; Published: June 30, 2017

*Corresponding author: Mark Stephen Umoh, Head of Department of Surgery, Faculty of Medicine College of Medical sciences, University of Calabar (UNICAL)/University of Calabar Teaching Hospital, (UCTH) UNICAL, Post Office Box 37713, Calabar Municipality, Cross River State, Nigeria, Email: imezuma2@gmail.com

\section{Introduction}

Circumcision is the most common surgical procedure performed worldwide. It is estimated that about $30 \%$ of human males have undergone the ritual, of whom Muslims comprises $70 \%$. Majority of neonatal circumcision are based on a complex array of medical, socio-cultural and religious reasons. The controversy continues-Neonatal circumcision or otherwise $[1,2]$. The clinical benefits of circumcision include reducing sexual transmitted disease (STD), Human Immunodeficiency virus (HIV) infection, Phimosis, Urinary tract infection (UTI) Penile cancer, cervical cancer in female mates; etc. The common complications include haemorrhage, infection and failure to remove enough foreskins, injury to the glans penis etc.

Circumcision is derived from the Latin word "Circumcido", meaning to cut around. Male circumcision is a surgical procedure consisting of the removal of the foreskin; the retractable fold of skin that covers the end of the penis (also known as the prepuce).The foreskin covers the head of the penis (glans penis) leaving a small exit at the tip for micturition. Circumcision is also called khitan in Islam or Brit milah (Bris) in Judaism [3]. The origin of circumcision came from ancient Egypt practice, which was performed to improve male hygiene. Then the religious circumcision was part of Abrahamic covenant with Jehovah. It is a commandment from God in Judaism but in Islam it is considered to be a Sunnah which is done between 9 and 12 years of age or not at all.

Neonatal method is commonly practiced by traditionalists and Christians. The procedure is suitable for babies who weigh at least $2.5 \mathrm{~kg}$ (5.5lb). There are diverse methods of circumcision but for the purpose of this discourse the Plastibell (a plastic circumcision device) is the method of choice. Plastibell can also be used for grown up or adult if the right size can be found. In the United States of America the three more commonly methods used are Gomco clamp, Mogen clamp and Plastibell in that order [4].

\section{When is the Best Time?}

Newborn period provides a window of opportunity for circumcision. The newborn, having recently experienced the considerable trauma of birth, has elevated levels of normal stress-resistance hormones. Babies heal quickly, are resilient, and use of local anesthesia means little or no pain. Since the inner and outer foreskin layers adhere to each other, sutures are rarely needed in babies.

Circumcision in the newborn period is safe and technically easy. It is also more convenient, not remembered by the male when grown, and is much cheaper, as well as providing the maximum lifetime benefit. Circumcision is a traditional and religious ceremony in many countries, and in Jewish culture. In Muslim societies, circumcision is 'the first step toward being a man and masculinity' and a sign of becoming a member of society and it is done between 9 and 12 years. I cannot remember what happened at my circumcision, then 8 days postnatal. Can you remember yours? Some may argue that because neonatal circumcision, commonly done without anesthesia is a form of man's inhumanity to man; all because the baby cannot talk but cry profusely. The practice continues while the debate rages on. The import is respect of parent's religious, ethnic or cultural beliefs for which the circumcision is practiced. However the advantages of circumcision outweigh the disadvantages.

There is no evidence of any long-term psychological harm arising from circumcision. The risk of damage to the penis is extremely rare and avoidable by using a competent, experienced doctor. Unfortunately, because it appears simple, low-risk procedure, it had once been the practice to assign this job to junior medical staff, with occasional devastating results. Many people including medical personnel regard this procedure as a minor operation (Figure 1).

In Nigeria most traditional birth attendants do it routinely for a fee. Anaesthesia is often not used, and the common 
complications include of haemorrhage, slicing the glans penis, removing more or less foreskin, infection, paraphimosis, etc. especially if it is not done by a specialist [5-8].

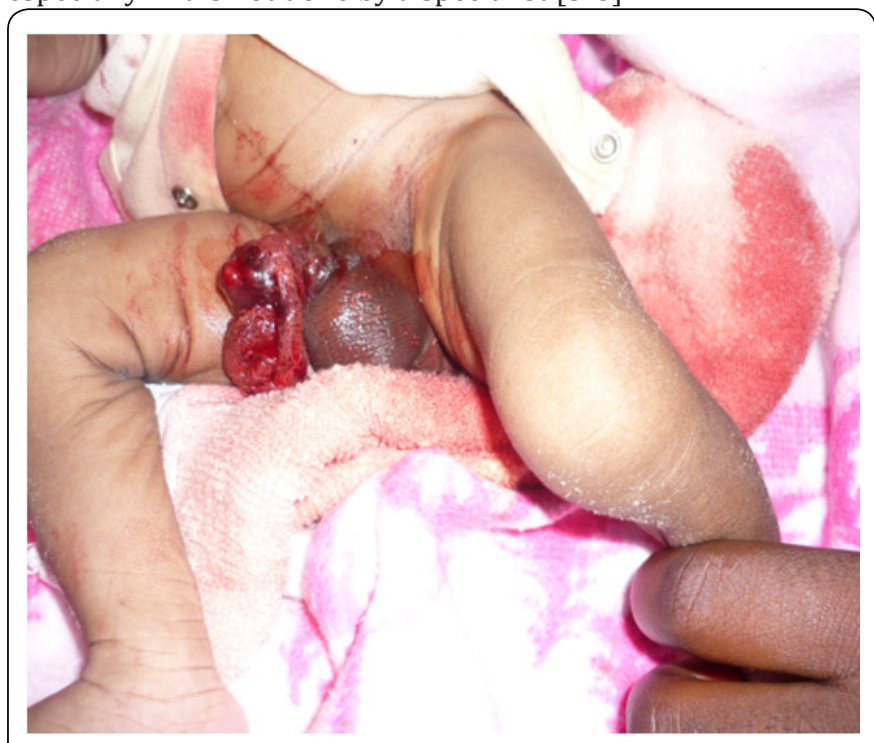

Figure 1: On admission.

Consider this advert, in one of Nigeria's big cities. Male circumsion available in this eye clinic. (A Bold Signpost, At Bus top). Listen to passerby "abina for free?"

So virtually anybody can circumcise a new born boy for some token or a bottle of genuine local gin and a fowl. The orthodox neonatal circumcision attracts between 20 \& 50 thousand Naira in Nigeria and 800- 2000 United States Dollars in the US, depending on the hospital, expertise of the operator and the method used. Although circumcision has been performed for cultural and religious reasons for thousands of years, most professional medical associations oppose routine neonatal circumcision and recommend the procedure only in cases where there are clearly defined medical reasons. But, is the procedure really a minor operation? [9]. Like many other practices in medicine Circumcision has pros and cons [10-12].

Plastibell method is one of the more commonly mode of circumcision in my centre (other than open surgical method). The Plastibell is a plastic device slipped between the penis and the foreskin to circumcise a male. A cut in the foreskin usually is required before the device can be placed. Sterile string is tied around the device and over the foreskin to cut off the blood supply. Foreskin tissue is trimmed off, leaving the ring tied in place. Tissue remaining under the ring dies and is sloughed off. The ring should fall off by itself about 10 to 12 days after the circumcision. Here I present to you a practical situation encountered with the Plastibell circumcision performed on the 8th dayas tradition demands (about seven 7yrs ago). I believe after this, you will know on which side of the divide you belong.

Circumcision at the age of 7 or 8 days is held as the ideal time for circumcision in many religions and cultural traditions. It is believed that this is an excellent age to perform circumcision with less bleeding and good healing and cosmesis (Figure 2).
Before asking a parent to sign a consent form, the doctor should provide up to date, scientific information about the health risks and benefits associated with circumcision. The baby people think they feel less pain, move less during the circumcision, can easily be restrained and will have no recollection of the operation. Most religious traditions recommend an early circumcision. I believe describing one of several scenarios may help decide if neonatal circumcision is a minor surgical procedure.

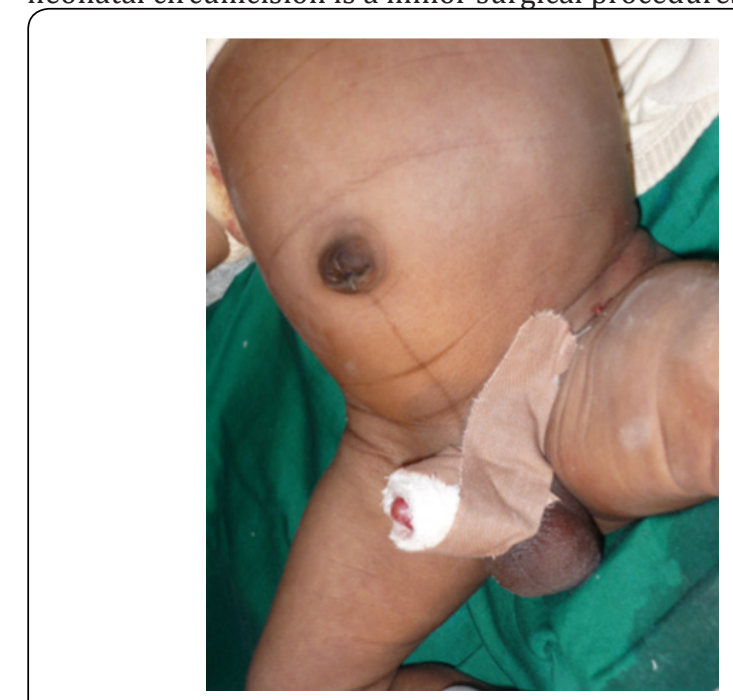

Figure 2: After bleed completed.

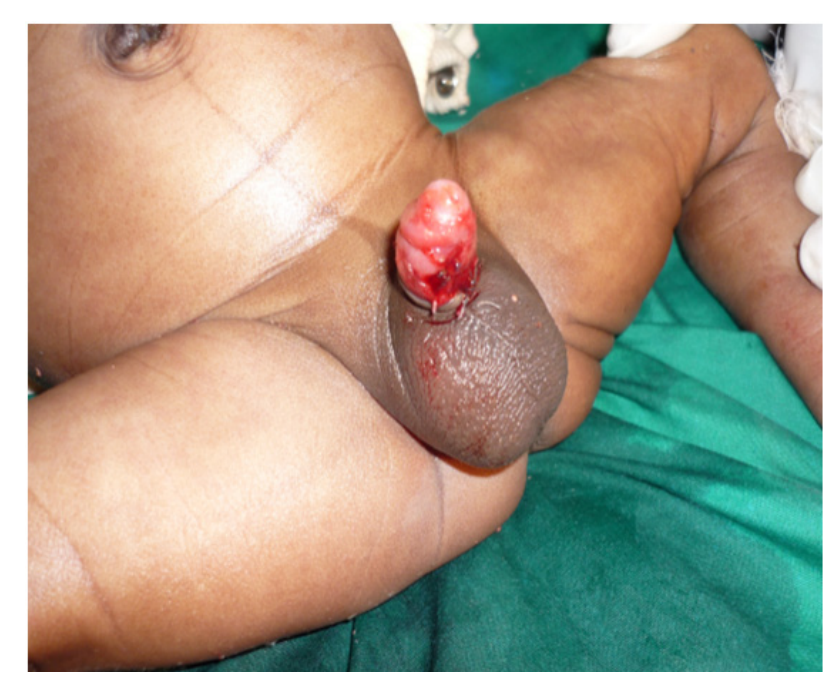

Figure 3: Child on $3^{\text {rd }}$ being discharged.

A woman was delivered of an active baby boy in Abuja in (about 500 kilometers from Calabar) with an APGAR score of 9, by a traditional birth attendant in December 8, 2010. Eight days later she tried to circumcise the neonate using the Plastibell method. The normal falling of the plastic on the expected day resulted in a frightening bleeding. They managed to bundle the baby to the nearest clinic (an army barracks medical centre) where all attempt to stop the bleeding proved abortive. Next port of call was the district general hospital; still the bleeding could not be stopped. The child was getting weaker, unable to cry out and whiter as time went on. Information got to the grandmother in Calabar about ten hours later and she furiously demanded 
that the child be flown to Calabar unaware of the state of the child. Hurriedly the attending physician arranged for transfer to Calabar, "to whom it may concern" with a sigh of relief (one would think,) at the insistence of the young primid. It took them another two and a half hours to get to MEVOM specialist clinic, Calabar, where the grandmother had insisted the child be taken (with no referral letter). Below are some of the photographs of the child as received, virtually exsanguinated, markedly dehydrated and unable to cry or suckle. Immediately the surgeon, anaesthetist, paediatrician and paediatric surgeon were reached (Figure 3).

Thanks to the Global Satellite Mobile (GSM) technology. On examination the child weighed 2.1 kilograms, something similar to water contaminated by blood was oozing all over the shaft and glans penis. The child was paper white wrapped with a baby blanket soaked with blood and no intravenous (IV) line. An IV line was urgently set up not without frustration, and blood spurned for packed cell volume (PCV) which was $10 \%$. A clinical diagnosis of exsanguinating haemorrhage after circumcision was made, to rule out congenital haemorrhagic disease, Haemophilia.

Haemophilia is one of the congenital haemorrhagic diseases. Factor V deficiency and Glanzman's disease are some others. Though often considered very rare in blacks it does occur. Patients with these conditions have a high risk of excessive and prolonged haemorrhage after all surgical procedures or trivial wounds. In known haemophiliac diathermic knife, factor substitution or fibrin glue is useful in the treatment for circumcision in these patients. It lessens the need for factor substitution after circumcision and thus reduces the high cost of treatment [13].

Fifteen millimeters $(15 \mathrm{mls})$ of blood from the mother was urgently transfused and oxygen administered to the infant. The child instantaneously regained strength as the cry improved, and the skin turned pinkish. He started suckling. We had no fibrin glue but managed to control further bleeding with sufratulle and sterile gauze bandaging. Antibiotics, anti-tetanus toxoid and analgesic were administered. For financial constraints the parents could not afford further investigations to confirm the suspected cause of the hemorrhage.

Transfusion was repeated after controlling the bleeding. By this time the child had started smiling and playing with the grandmother who was anxiously waiting and sobbing outside the theatre. The grandmother was very excited because she got a grandchild life. If the child had died it would be traditionally assumed she used the child's life to extend her stay on earth. She was vindicated.

The child was lost to follow-up after six months. At age 3years, the child sustained a minor injury at home while playing and bled for 3 days. He later presented in the hematology consulting clinic of the University of Calabar Teaching Hospital where the definitive diagnosis of Hemophilia A, was made. He was started him on coagulation factor VIII concentrate. He made remarkable improvement and had since gone back to the parents. The case was presented at the interdepartmental monthly meeting. He was being managed and followed up by the hematology department till 5yrs, when he defaulted again. Story has it that he is now with parents in Abuja attending an elite school. Typical of poor followup compliance by patients, in Nigeria.

\section{Conclusion}

Circumcision should not be performed without a qualified health professional and a sanitary environment. Now modern techniques of proper and safe circumcision should be taught to medical students and practitioners because it is performed so commonly and needs to be done well. The procedure becomes less simple the older than child becomes.

Circumcision is not a minor procedure and government should promulgate a regulation to protect these innocent children from the hands of quacks and non-specialists. It will go a long way to reducing the alarmingly high child morbidity and mortality in Nigeria. No surgical procedure is minor, neither incision and drainage, nor the crude and wicked act of abortion popularly referred to as Dilatation and curettage (D\&C or TOP). Neonatal male circumcision as the case described and references to other experienced paediatric surgeons' reports in the world literature do prove that the procedure should not be considered minor.

\section{References}

1. Weiss GN, Weis EB (1994) A perspective on controversies over neonatal circumcision. Clin Pediatr (Phila) 33(12): 726-730.

2. Schoen EJ (1990) The status of circumcision of newborns. N Engl J Med 322(18): 1308-1312.

3. Laumann EO, Masi CM, Zuckerman EW (1997) Circumcision in the United Stated. Prevalence, prophylactic effects and sexual practice. JAMA 277(13): 1052-1057.

4. https//en.wikilipedia.org/wiki/Circumcision_surgical_procedure.

5. Wiess HA, Larke N, Halperin D, Schenker I (2010) Circumcision in neonates, infants and children: a systematic review. BMC Urol 10: 2.

6. Pieretti RV, Goldstein AM, Pieretti-Vanmarcke R (2010) Late complications of newborn circumcision: a common and avoidable problem. Pediatr Surg Int 26(5): 515-518.

7. Osifo OD, Oriaifo IA (2009) Circumcision mishaps in Nigerian children. Ann Afr Med 8(4): 266-270.

8. Bode CO, Ikhisemojie S, Ademuyiwa AO (2010) Penile injuries from proximal migration of the Plastibell circumcision ring J Pediatr urol 6(1): 23-27.

9. Cost or prize of the operation.

10. Burgu B, Aydogdu O, Tangal S, Soygur T (2010) Circumcision: Pros and cons. Indian J Urol 26(1): 12-15.

11. Schoen EJ (2007) Should newborns be circumcised? Yes. Can Fam physician 53(12): 100-102.

12. Milos MF, Macris D (1992) Circumcision. A medical or human rights issue? J Nur Mid 37(2): 87-96

13. Karaman MI, Zulfikar B, Caskurlu T, Ergenekon E (2004) Circumcision in hemophilia: a cost-effective using a novel device. J Pediatr Surg 39(10): 1562-1564. 
This work is licensed under Creative Commons Attribution 4.0 Licens DOI: 10.19080/GJIDD.2017.01.555571
Your next submission with Juniper Publishers will reach you the below assets

- Quality Editorial service

- Swift Peer Review

- Reprints availability

- E-prints Service

- Manuscript Podcast for convenient understanding

- Global attainment for your research

- Manuscript accessibility in different formats ( Pdf, E-pub, Full Text, Audio)

- Unceasing customer service

Track the below URL for one-step submission https://juniperpublishers.com/online-submission.php 